PREMIERE : Journal of Islamic Elementary Education Vol 3 No 1 | Tahun 2021

\title{
PENINGKATAN PRESTASI BELAJAR IPS MENGGUNAKAN MEDIA KARTU BERGAMBAR (DRAW CARD)
}

${ }^{1)}$ Nurlaili Dina Hafni, IAINU Tuban, e-mail : dinahafni@ stitmatuban.ac.id

\begin{abstract}
To upgrade learning achievement in Social Studies (IPS), the authors use the media with picture cards (Draw Card), the authors choose picture cards because these media are common media and easy to understand by students. This media also has the aim of attracting students' attention, clarifying the material, illustrating facts or information that will be quickly understood if illustrated with pictures. In addition, drawing card media (Draw Card) can be made easily and used according to the creativity of educators based on the material to be delivered.

After observing and evaluating, the progress of students in the study of Increasing Learning Achievement in Social Studies (IPS) Using Picture Card Media (Draw Card) in class VI students of SDN Tasikmadu 02 Palang District, Tuban Regency. It can be concluded as follows (1) The application of illustrated card media (Draw Card) can be carried out properly and structured by researchers, implementation activities are carried out through pre-cycle activities, then cycle I and continues in cycle II. (2) Student achievement continues to show a significant increase compared to before using the media, student achievement tends to be low, namely 0 or no students who complete the minimum completeness criteria that have been set. It can be seen that the social studies learning achievement of 18 students, there are 18 students or $100 \%$ who get a complete score (T) and 0 students or $0 \%$ of students get an incomplete score (TT). His class average is 90. (3) Social Studies (IPS) learning achievement by using drawing card media (Draw Card) has increased which can be seen from the average value and classical completeness presentation, the pre-cycle value shows an average of $53.89 \%$ with the percentage of students who complete 0\%. After the implementation of the picture card media in the first cycle, the formative test results reached $70 \%$ with the percentage of students who completed 9 and students who did not complete 9, in the second cycle an average increase of $90 \%$ and has reached the indicator of success of classical completeness, namely at least $85 \%$ of the total number of students. This shows that the use of picture card media (Draw Card) can improve Social Studies learning achievement.
\end{abstract}

Keywords : social studie, draw card

\section{Pendahuluan}

Pendidikan merupakan usaha manusia untuk menyiapkan diri dalam peranannya dimasa akan datang. Pendidikan dilakukan tanpa ada batasan usia, ruang dan waktu yang tidak dimulai atau diakhiri di sekolah, tetapi diawali dalam keluarga dilanjutkan dalam lingkungan sekolah dan diperkaya oleh lingkungan masyarakat, yang hasilnya digunakan untuk membangun kehidupan pribadi agama, masyarakat, keluarga, dan negara. Merupakan suatu kenyataan bahwa pemerintah dalam hal ini diwakili lembaga yang bertanggung jawab di dalam pelaksanaan pendidikan di Indonesia, akan tetapi pendidikan menjadi tanggung jawab keluarga, sekolah, dan masyarakat 
yang sering disebut dengan Tri Pusat Pendidikan.

Penerapan pendidikan di Indonesia masih terkendala oleh beberapa hal, seperti sarana dan prasarana yang kurang memadai, latar belakang siswa, kurangnya penguasaan pendidik terhadap materi yang disampaikan, serta kurang efektifnya media pembelajran yang digunakan pada saat pembelajaran turut menjadi penyebab perkembangan pendidikan saat ini. Dengan menggunakan strategi, pendekatan, dan metode yang tepat dan sesuai dengan keadaan kelas akan sangat membantu guru untuk menyampaikan materi pembelajaran yang ingin disajikan dan peserta didik juga akan sangat mudah memahami materi tersebut.

Berhasilnya tujuan pembelajaran ditentukan oleh banyak faktor diantaranya adalah faktor guru dalam melaksanakan proses belajar mengajar, karena guru secara langsung dapat mempengaruhi, membina, dan meningkatkan kecerdasan serta keterampilan siswa. Untuk mengatasi permasalahan di atas dan guna mencapai tujuan pendidikan secara maksimal, peran guru sangat penting dan diharapkan guru memiliki cara atau model mengajar yang baik dan mampu memilih model pembelajaran yang tepat dan sesuai dengan konsep-konsep mata pelajaran yang akan disampaikan.

Permasalahan yang dialami oleh siswa kelas VI adalah padatnya materi pelajaran Ilmu Pengetahuan Sosial (IPS) yang harus dipelajari, sehingga siswa kurang mampu untuk memahami, mengingat atau menghafalkan semua materi yang ada, hal ini merupakan sebuah tantangan bagi guru untuk memaksimalkan semua kemampuan yang dimiliki. Peran guru sangat besar dalam menyampaikan semua materi pelajaran, guru harus sebisa mungkin menyampaikan semua meteri yang ada pada siswa dengan mengoptimalkan alokasi waktu yang ada.

Yang terjadi pada umumnya pada pembelajaran Ilmu Pengetahuan Sosial (IPS) siswa hanya memfungsikan indera pendengaran saja sehingga untuk memahami konsep-konsep yang abstrak siswa mengalami kesulitan. Selain itu, dalam penyampaian suatu konsep, guru belum sepenuhnya menggunakan strategi pembelajaran yang tepat. Kegiatan pembelajaran yang dilakukan lebih banyak menggunakan metode ceramah tanpa didukung metode pembelajaran yang lain atau alat bantu mengajar yang bervariasi sehingga pembelajaran tampak monoton.

Mengingat permasalahan diatas, maka diperlukan suatu pembelajaran yang efektif dan menggunakan media yang menarik agar tujuan pembelajaran Ilmu Pengetahuan Sosial (IPS) khususnya pada materi perkembangbiakan hewan dapat tercapai. Dalam upaya meningkatkan prestasi belajar Ilmu Pengetahuan Sosial (IPS), penulis menggunakan media kartu bergambar 
(Draw Card), penulis memilih media kartu bergambar karena media tersebut merupakan media yang umum dan mudah dimengerti oleh siswa. Media ini juga memiliki tujuan untuk menarik perhatian siswa, memperjelas materi, mengilustrasikan fakta atau informasi yang akan cepat dipahami jika diilustrasikan dengan gambar ${ }^{1}$. Selain itu, media kartu bergambar (Draw Card) dapat dibuat dengan mudah dan digunakan sesuai dengan kreatifitas pendidik berdasarkan materi yang akan disampaikan.

Di Sekolah Dasar (SD), Ilmu Pengetahuan Sosial dimaksudkan agar siswa mempunyai pengetahuan, gagasan dan konsep tentang alam sekitar, yang diperoleh dari pengalaman melalui serangkaian proses ilmiah antara lain penyelidikan, penyusunan dan penyajian gagasan-gagasan. Pada prinsipnya, mempelajari IPS sebagai cara mencari tahu dan cara mengerjakan atau melakukan dan membantu siswa untuk memahami keadaan sosial sekitar secara lebih mendalam.

Media yang digunakan dalam materi ini adalah kartu bergambar (Draw Card). Dengan menggunakan media siswa sekolah dasar akan lebih memahami, mengerti dan memaknai materi yang sedang ia pelajari sehingga terbentuk konsep atau pemikiran yang tak mudah dilupakan. Mengingat betapa pentingnya pembelajaran IPS, maka salah satu cara untuk memperbaiki mutu prestasi belajar IPS di Madrasah Ibtidaiyah adalah melaksanakan pembelajaran yang tepat dalam proses pembelajaran pada masing-masing pokok bahasan.

Penilitian tindakan kelas (PTK) sengaja dipakai oleh peneliti untuk mengkaji masalah pembelajaran di dalam kelas melalui refleksi diri dalam upaya untuk memecahkan masalah tersebut dengan cara melakukan berbagai tindakan yang terencana dalam situasi nyata serta menganalisis pengaruh dari perlakuan tersebut ${ }^{2}$. Hal ini sesuai dengan model penelitian dari Kurt Lewin yang menyatakan bahwa dalam satu siklus terdiri dari empat langkah pokok yaitu (1) planning (rencana), (2) action (tindakan), (3) observation (pengamatan), (4) reflection (refleksi). Melihat permasalahan yang dihadapi guru mengenai kurangnya pemahaman siswa pada prlajaran IPS kelas VI SDN Tasikmadu 02 Palang, maka dipilih media kartu bergambar untuk meningkatkan prestasi belajar siswa

\footnotetext{
${ }^{1}$ Kustandi, Cecep dan Bambang Sutjipto. Media Pembelajaran; Manual dan Digital. (Bogor: Ghalia Indonesia, 2011) hal 25

${ }^{2}$ Sanjaya, Wina. Penelitian Tindakan Kelas (Jakarta : Prenadamedia Group. 2009), hal 26
} 


\section{Metodologi}

Penelitian ini menggunakan jenis Penelitian Tindakan Kelas (PTK). PTK berasal dari istilah classroom action research (CAR). PTK merupakan sebuah kegiatan penelitian yang bertujuan untuk memperbaiki kekurangan-kekurangan yang terdapat dalam pembelajaran di kelas, yaitu dengan cara melakukan tindakan-tindakan tertentu agar dapat memperbaiki serta meningkatkan kualitas pembelajaran sehingga tujuan pembelajaran yang diharapkan dapat tercapai. Dari Penjelasan diatas, maka PTK dapat diartikan sebagai proses pengkajian masalah pembelajaran di dalam kelas melalui refleksi diri dalam upaya untuk memecahkan masalah tersebut dengan cara melakukan berbagai tindakan yang terencana dalam situasi nyata serta menganalisis setiap pengaruh dari perlakuan tersebut ${ }^{3}$. Dalam PTK terdapat empat tahapan uaitu perencanaan, tindakan, observasi dan refleksi.

Adapun pendekatan dalam penelitian ini adalah menggunakan pendekatan statistik deskriptif. Statistik deskriptif adalah statistik yang berfungsi untuk mendiskripsikan atau memberi gambaran terhadap obyek yang diteliti melalui data sampel atau populasi sebagaimana adanya, tanpa melakukan analisis dan kesimpulan yang berlaku utuk umum. Penelitian ini dilakukan di SDN Tasikmadu 02 Palang kabupaten Tuban, tepatnya di kelas VI dengan jumlah siswa 18 orang, 12 orang laki-laki dan orang perempuan. Kelas VI SDN Tasikmadu 02 Palang ini memiliki kelemahan pada mata pelajaran IPS, dimana mereka kurang bias focus dan kurang mampu memahami materi pelajaran karena banyak hafalan.

\section{Hasil}

Penelitian ini dilakukan dalam tahapan pra siklus, siklus I dan siklus II yang dijabarkan sebagai berikut.

\section{Pra Siklus}

Tahap prasiklus adalah tahap dimana belum diterapkannya media pembelajaran yang baru. Kegiatan pra siklus dilaksanakan peneliti dikelas VI SDN Tasikmadu 02 Tahap ini bertujuan untuk mengetahui seberapa jauh keaktifan dan kemampuan peserta didik dalam pembelajaran IPS di kelas sebelum diterapkannya media pembelajaran kartu bergambar (Draw Card).

\footnotetext{
${ }^{3}$ Ibid.
} 
Pada saat proses pembelajaran peneliti mengamati setiap aktivitas guru dan siswa serta perolehan prestasi belajar siswa setelah dilakukannya pre tes, untuk dijadikan sebagai acuan dalam proses perbaikan dalam penelitian tindakan kelas ini. Adapun prestasi belajar siswa yang peneliti peroleh dari pengamatan pra siklus dapat dilihat dibawah ini:

Tabel Rekapitulasi Nilai Pra Siklus

\begin{tabular}{|l|c|c|}
\hline \multirow{2}{*}{ Rekapitulasi } & \multicolumn{2}{|c|}{ Pra Siklus } \\
\cline { 2 - 3 } & $\mathbf{2}$ & \multicolumn{2}{|c|}{970} \\
\hline Jumlah Nilai & \multicolumn{2}{|c|}{53,89} \\
\hline Rata-Rata & \multicolumn{2}{|c|}{$0 \%$} \\
\hline Tuntas & 0 & \multicolumn{2}{c|}{$0 \%$} \\
\hline Tidak Tuntas & 18 & $100 \%$ \\
\hline
\end{tabular}

Dari table diatas, diperoleh hasil penelitian dengan mengetahui proses pembelajaran yang dinyatakan tuntas (T) ataupun tidak tuntas (TT) yang berdasar pada nilai KKM Madrasah yaitu 70 seperti tertera dalam tabel bahwa siswa yang belum tuntas (BT) 18 siswa dan yang sudah tuntas (T) 0 siswa dan mendapat rata-rata 53,89 artinya tingkat keberhasilannya siswa 0 dan $100 \%$ dinyatakan belum tuntas.

Setelah dilakukannya pre tes pada saat pra siklus diperoleh hasil bahwa tidak ada siswa yang tuntas dalam mengerjakan soal yang diberikan guru, ini dibuktikan dengan prestasi belajar siswa yang kurang dari standar kriteria ketuntasan minimal (KKM) yaitu 70, hal tersebut dijadikan acuan oleh peneliti untuk memperbaiki prestasi belajar siswa dengan melakukan tindakan pada setiap siklusnya.

\section{Siklus I}

\section{a) Perencanaan}

Berdasarkan pengamatan prestasi belajar yang diperoleh dari nilai pra siklus, peneliti melakukan perbaikan dengan melakukan tindakan pada siklus I yang mana pada tindakan ini peneliti menggunakan media pembelajaran kartu bergambar (Draw Card). Pada kesempatan ini peneliti berdiskusi dengan pihak yang bersangkutan terkait kegiatan yang akan dilakukan pada siklus I. Adapun yang harus disiapkan oleh peneliti pada siklus I yaitu: Rencana Pelaksanaan Pembelajaran (RPP) menyiapkan sumber belajar dan media pembelajaran berupa kartu bergambar, menyiapkan lembar observasi guru dan siswa, dan lembar tes formatif siklus I serta materi IPS. 


\section{b) Tindakan}

Setelah merumuskan perencanaan di awal sebelum penelitian, maka peneliti melakukan tindakan (action) pada siklus I, adapun pelaksanaan tindakan akan dijabarkan sebagai berikut:

1. Membuka pembelajaran dengan salam, doa, mengabsen peserta didik, memberikan motivasi serta melakukan appersepsi.

2. Bertanya kepada siswa tentang materi lalu dan menghubungkan dengan materi yang akan disampaiakan

3. Menjelaskan materi tentang ciri-ciri perkembangbiakan hewan

4. Siswa mencatat materi tentang ciri-ciri perkembangbiakan hewan

5. Guru menunjukkan kartu bergambar yang berisi tentang gambar hewan yang relevan dengan materi

6. Siswa memperhatikan gambar yang ditunjukkan oleh peneliti

7. Peneliti mengadakan observasi kepada siswa

8. Setelah selesai menunjukkan kartu bergambar, peneliti mengulas materi berdasarkan media yang digunakan

9. Guru memberikan kesempatan untuk bertanya kepada siswa tentang hal-hal yang belum jelas

10. Guru membagi siswa menjadi 4 kelompok setiap kelompok terdiri dari 3-4 siswa

11. Guru membagikan kartu bergambar kepada masing-masing kelompok sesuai dengan jumlah anggotanya

12. Siswa diminta untuk berdiskusi tentang kartu bergambar yang mereka dapat

13. Guru memimpin jalannya diskusi

14. Sesuai dengan intruksi Guru, secara bergiliran masing-masing kelompok maju ke depan untuk mempresentasikan hasil diskusi kelompoknya dan menempelkan kartu bergambar yang mereka dapat pada tabel yang sudah disiapka di papan tulis.

15. Guru Bersama kelompok lain menanggapi hasil diskusi kelompok tersebut.

16. Guru Bersama siswa memberikan apresiasi atas hasil kerja kelompok tersebut

17. Guru melakukan konfirmasi pada hasil kerja kelompok

18. Guru membagikan lembar tugas individu untuk mengetahui hasil belajar siswa pada siklus I 
19. Guru memberikan motivasi belajar kepada peserta didik

20. Guru mengucapkan salam penutup

Adapun perolehan nilai dari tes formatif pada siklus I setelah dilakukan tindakan penerapan media kartu bergambar pada materi IPA adalah sebagai berikut:

Tabel Rekapitulasi Nilai Tes Siklus I

\begin{tabular}{|l|c|c|}
\hline \multirow{2}{*}{ Rekapitulasi } & \multicolumn{2}{c|}{ Siklus I } \\
\cline { 2 - 3 } & \multicolumn{3}{|c|}{1,260} \\
\hline Jumlah Nilai & \multicolumn{3}{|c|}{70} \\
\hline Rata-Rata & 9 & \\
\hline Tuntas & 9 & $50 \%$ \\
\hline Tidak Tuntas & & $50 \%$ \\
\hline
\end{tabular}

Dari data hasil prestasi belajar siswa setelah dilaksanakan pembelajaran dengan media kartu bergambar, dapat diketahui bahwa prestasi belajar IPA siswa kelas VI MI Al Masykuriyah Dawung yang berjumlah 18 siswa, ada delapan siswa atau $50 \%$ yang mendapatkan nilai tuntas dan 8 siswa atau $50 \%$ lainnya masih di bawah kriteria ketuntasan minimal. Adapun nilai rata-rata kelasnya adalah 70.

\section{c) Observasi}

Pada tahap ini dilakukan observasi atau pengamatan pada proses pembelajaran berlangsung dan mencatatnya dengan alat observasi tentang hal-hal yang akan diamati atau diteliti. Pada tahap ini yang diamati adalah peningkatan aktivitas guru dalam mengelola pembelajaran serta penggunaan media secara efektif, sedangkan aktivitas siswa diamati dari keaktifan, kerjasama dan tanggung jawab, begitu juga nilai yang diperoleh dari tes formatif untuk mengetahui pemahaman siswa pada materi yang diajarkan.

Kegiatan observasi dilakukan peneliti untuk mengetahui aktivitas guru dan siswa juga untuk melihat semangat minat, keaktifan peserta didik dalam mengikuti pembelajaran dengan menggunakan media kartu bergambar (Draw Card). Adapun hasil pengamatan yang peneliti peroleh dari penerapan media kartu bergambar pada siklus I ini, dapat peneliti jelaskan sebagai berikut: 
Tabel Hasil Pengamatan Aktivitas Guru Pada Siklus I

\begin{tabular}{|l|c|c|c|c|c|}
\hline \multicolumn{1}{|c|}{$\begin{array}{c}\text { Banyak Aspek yang Diamati } \\
\text { (20 Aspek) }\end{array}$} & \multicolumn{4}{|c|}{ Jumlah } \\
\cline { 2 - 6 } & A & B & C & D & 56 \\
\hline Skor Perolehan & & 6 & 2 & - & \\
\hline Skor Maksimal & & 0 & 0 & - & \\
\hline Presentase hasil observasi siklus I & \multicolumn{6}{|c|}{$70 \%$} \\
\hline
\end{tabular}

Berdasarkan pada tabel diatas diketahui bahwa aktivitas guru dalam proses pembelajaran dalam menggunakan media kartu bergambar mencapai $70 \%$, ini sudah baik namun masih perlu ditingkatkan lagi agar proses pembelajaran lebih optimal. Selain aktivitas guru peneliti juga menjelaskan hasil pengamatan aktivitas siswa, adapun hasilnya sebagai berikut:

Tabel Hasil Pengamatan Aktivitas Siswa

\begin{tabular}{|c|l|c|c|c|c|c|c|c|c|}
\hline \multirow{2}{*}{ No } & Aspek yang diamati & \multicolumn{9}{|c|}{ Aspek yang diamati } \\
\cline { 3 - 10 } & & \multicolumn{3}{|c|}{ A } & \multicolumn{3}{|c|}{ B } & \multicolumn{3}{|c|}{ C } & \multicolumn{2}{c|}{ D } \\
\hline 1 & Keaktifan & 3 & $16,7 \%$ & 4 & $22,22 \%$ & 7 & $38,9 \%$ & 5 & $27,8 \%$ \\
\hline 2 & Kerjasama & 2 & $11,11 \%$ & 3 & $16,7 \%$ & 8 & $44,44 \%$ & 6 & $33,33 \%$ \\
\hline 3 & Tanggung Jawab & 3 & $16,7 \%$ & 2 & $11,11 \%$ & 7 & $38,9 \%$ & 7 & $38,9 \%$ \\
\hline
\end{tabular}

Dari hasil Pengamatan aktivitas siswa setelah dilaksanakan pembelajaran yang meliputi Keaktifan, Kerjasama, dan Tanggung jawab dengan menggunakan media kartu bergambar, dapat diketahui bahwa aktivitas belajar IPS untuk :

1. Keaktifan yang mendapatkan $A=3$ siswa, $B=4$ siswa, $C=7$ siswa, dan $D=5$ siswa

2. Kerjasama yang mendapatkan $\mathrm{A}=2$ siswa, $\mathrm{B}=3$ siswa, $\mathrm{C}=8$ siswa, dan $\mathrm{D}=6$ siswa

3. Tanggung jawab_yang mendapatkan $\mathrm{A}=3$ siswa, $\mathrm{B}=2$ siswa, $\mathrm{C}=7$ siswa, dan $\mathrm{D}=7$ siswa.

Berdasarkan hasil pengamatan aktivitas siswa pada siklus I menunjukkan bahwa terdapat beberapa siswa masih kurang berpartisipasi dalam pembelajaran, maka dari itu perlu adanya tindak lanjut pada siklus II dengan harapan untuk mendapatkan hasil yang lebih baik lagi. 


\section{d) Refleksi}

Berdasarkan hasil observasi peneliti dan pihak yang bersangkutan melakukan analisis terhadap proses pembelajaran dengan berdikusi dan mengevaluasi pembelajaran yang telah dilaksanakan. Serta melihat kekurangan dalam proses pembelajaran. Berikut adalah hasil analisis yang berpedoman pada indikator dan lembar observasi penguasaan yang menjelaskan cara perkembangbiakan hewan:

1. Sebagian besar anak tertarik, antusias, semangat dengan media yang telah diterapkan oleh peneliti

2. Terbatasnya waktu pada saat anak diminta satu-persatu mengulang untuk menjelaskan cara perkembangbiakan hewan.

3. Sudah ada peningkatan dalam menjelaskan cara perkembangbiakan hewan, jika dibandingkan dengan sebelum menggunakan media kartu bergambar, hasil tersebut belum maksimal artinya peneliti perlu memperbaiki proses pembelajaran.

Dari hasil analisis tersebut, peneliti dan pihak yang bersangkutan merasa bahwa hasil penelitian belum maksimal. Oleh sebab itu peneliti melanjutkan tindakan pada siklus II.

\section{Siklus II}

\section{a) Perencanaan}

Dalam perencanaan siklus II peneliti mengacu pada hasil pembelajaran pada Siklus I yang pada umumnya sudah baik. Namun belum memenuhi indikator keberhasilan yaitu $85 \%$ , pada siklus I masih ada anak yang belum menguasai materi yang diajarkan. Untuk mengatasi kekurangan pada Siklus I, maka peneliti dan pihak yang bersangkutan merencanakan tindakan pada siklus II. Adapun perencanaanya sebaagai berikut:

1. Peneliti menyiapkan rencana pelaksanaan pembelajaran (RPP)

2. Menyiapkan materi pembelajaran, sumber belajar dan media pembelajaran kartu bergambar.

3. Menyiapkan lembar observasi guru dan siswa, serta lembar tes formatif siklus II

\section{b) Tindakan}

Pada tahapan tindakan siklus II peneliti masuk kelas VI sesuai dengan jadwal yang sudah ditentukan sebelumnya, peneliti mengucapkan salam, melakukan presensi dan juga appersepsi, serta mengadakan sesi tanya jawab tentang perkembangbiakan hewan yang telah 
diajarkan pada pertemuan yang lalu, Peneliti kembali menunjukkan kartu bergambar untuk ditempel pada tabel, secara acak peneliti membagikan kartu bergambar pada masing-masing kelompok, Peneliti meminta siswa untuk memperhatikan dan mengidentifikasi gambar. Peneliti meminta masing-masing kelompok menempelkan kartu bergambar pada tabel yang sesuai dengan gambar yang didapat, siswa berdiskusi dengan gambar yang mereka terima, Peneliti memanggil kelompok yang sudah siap maju untuk menempelkan kartu bergambar, secara individu masing-masing siswa menjelaskan jawaban yang telah didiskusikan bersama kelompoknya. Adapun nilai yang diperoleh setelah dilakukannya tindakan pada siklus II dapat peneliti jelaskan sebagai berikut:

Tabel Rekapitulasi Nilai Tes Siklus II

\begin{tabular}{|c|c|c|}
\hline \multirow[t]{2}{*}{ Rekapitulasi } & \multicolumn{2}{|c|}{ Siklus II } \\
\hline & $\Sigma$ & $\%$ \\
\hline Jumlah Nilai & \multicolumn{2}{|c|}{1,620} \\
\hline Rata-Rata & \multicolumn{2}{|c|}{90} \\
\hline Tuntas & 18 & $100 \%$ \\
\hline Tidak Tuntas & 0 & $0 \%$ \\
\hline
\end{tabular}

Dari data hasil prestasi belajar siswa setelah dilaksanakan pembelajaran dengan media kartu bergambar, dapat diketahui bahwa prestasi belajar IPS yang berjumlah 18 siswa, ada 18 siswa atau $100 \%$ yang mendapatkan nilai tuntas (T) dan 0 siswa atau $0 \%$ siswa mendapatkan nilai tidak tuntas (TT). Nilai rata-rata kelasnya adalah 90.

\section{c) Observasi}

Kegiatan observasi dilakukan pada saat pembelajaran belangsung. Peneliti melakukan untuk mengetahui peningkatan aktivitas guru dan siswa juga prestasi belajar siswa setelah dilakukan tindakan pada siklus II yang menerapkan media kartu bergambar.

Setelah memperbaiki kekurangan pada siklus I pengamatan kembali dilakukan pada siklus II untuk mengetahui peningkatan aktivitas guru dan siswa dalam proses pembelajaran dengan menggunakan media kartu bergambar (Draw Card), hasil yang peneliti peroleh dari pengamatan siklus II ini dijelaskan peneliti sebagai berikut: 
Tabel Hasil Pengamatan Aktivitas Guru Pada Siklus II

\begin{tabular}{|c|c|c|c|c|c|}
\hline \multirow{2}{*}{$\begin{array}{c}\text { Banyak Aspek yang Diamati (20 } \\
\text { Aspek) }\end{array}$} & & & & & \multirow{2}{*}{ Jumlah } \\
\hline & $\mathbf{A}$ & B & $\mathbf{C}$ & $\mathbf{D}$ & \\
\hline Skor Perolehan & 6 & 3 & - & & 69 \\
\hline Skor Maksimal & 0 & 0 & - & & \\
\hline Presentase hasil observasi siklus II & \multicolumn{5}{|c|}{$86,25 \%$} \\
\hline
\end{tabular}

Berdasarkan pada tabel diatas diketahui bahwa aktivitas guru dalam proses pembelajaran dalam menggunakan media kartu bergambar sudah sangat baik, guru mampu menerapkan media kartu bergambar secara optimal dan membuat pembelajaran lebih efektif dan efesien, untuk hasil pengamatan aktivitas siswa di jelaskan peneliti sebagai berikut:

Tabel Pengamatan Aktivita Siswa iklus II

\begin{tabular}{|l|l|c|c|c|c|c|c|c|c|}
\hline \multirow{2}{*}{ No } & \multirow{2}{*}{ Aspek yang diamati } & \multicolumn{9}{c|}{ Aspek yang diamati } \\
\cline { 3 - 10 } & & \multicolumn{2}{|c|}{ A } & \multicolumn{3}{c|}{ B } & \multicolumn{2}{c|}{ C } & \multicolumn{2}{c|}{ D } \\
\hline 1 & Keaktifan & 8 & $44,44 \%$ & 9 & $50 \%$ & 1 & $5,55 \%$ & - & - \\
\hline 2 & Kerjasama & 10 & $55,55 \%$ & 8 & $44,44 \%$ & - & - & - & - \\
\hline 3 & Tanggung Jawab & 11 & $61,11 \%$ & 7 & $38,89 \%$ & - & - & - & - \\
\hline
\end{tabular}

Berdasarkan hasil pengamatan aktivitas siswa diatas dapat diketahui bahwa hasil dari ketiga aspek pengamatan yang telah diamati yakni meliputi keaktifan, kerjasama serta tanggung jawab mengalami peningkatan yang signifikan hal ini terlihat pada siklus I yang mana masih ada beberapa siswa yang kurang aktif dalam pembelajaran, namun setelah dilakukan perbaikan pada siklus II, hampir seluruh siswa berminat, antusias dan aktif dalam pembelajaran.

\section{d) Refleksi}

Berdasarkan hasil observasi dan menganalisis proses tindakan pada Siklus II, peneliti tidak menemukan kendala, proses pembelajaran berjalan sangat lancar, kelemahan yang ada pada Siklus I dapat teratasi. hal ini dapat menjadikan kualitas pembelajaran perkembangbiakan hewan meningkat.. Dari kedua siklus ini dapat disimpulkan bahwasannya:

1. Penerapan media kartu bergambar (Draw Card) dapat meningkatkan prestasi belajar IPS. Peningkatan kualitas pembelajaran dapat dilihat dari tercapainnya indikator yang ditetapkan, yaitu tampak peningkatan pemahaman tentang penjelasan perkembangbiakan hewan dari siklus I dan Siklus II 
2. Prestasi belajar siswa dibuktikan pada hasil penelitian yang dicapai dua siklus pada mata pelajaran Ilmu Pengetahuan Sosial dengan menggunakan media kartu bergambar (Draw Card) menunjukkan bahwa kemampuan memahami perkembangbiakan hewan beserta ciri-cirinya sudah sangat memuaskan dan menunjukkan peningkatan pada tiap siklusnya.

3. Peningkatan prestasi belajar siswa dibuktikan pada hasil penelitian yang dicapai dua siklus pada mata pelajaran Ilmu Pengetahuan Sosial (IPS) dengan menggunakan media kartu bergambar (Draw Card). Prestasi siswa menunjukkan peningkatan yang sangat baik yaitu siklus I sebesar 50\% dan pada Siklus II mencapai 100\%.

\section{Pembahasan}

Setelah penelitian selesai dilaksanakan dalam dua siklus yang mana setiap siklusnya mengalami peningkatan yang cukup signifikan, maka dalam pembahasan ini peneliti akan menjelaskan poin yang liner dengan jumlah rumusan masalah dan tujuan penelitian.

1) Berdasarkan hasil penelitian tindakan kelas, bahwa penerapan media kartu bergambar dapat meningkatkan prestasi belajar. Hal ini dikarenakan media kartu bergambar termasuk media visual yang berfungsi untuk menyampaikan materi pelajaran kepada siswa agar lebih mudah. Alasan tersebut diperkuat oleh Sulaiman yaitu "gambar merupakan alat visual yang penting dan mudah didapat”. Lebih lanjut Sulaiman menjelaskan bahwa media gambar penting sekali sebab dapat memberikan penggambaran visual yang konkrit tentang masalah yang digambarkan. Gambar memungkinkan orang menangkap informasi lebih jelas daripada yang hanya disampaikan dengan kata-kata atau tulisan saja.

2) Adapun prestasi belajar siswa setelah menggunakan media kartu bergambar (Draw Card) terlihat mengalami peningkatan yang signifikan dalam penguasaan pengetahuan atau keterampilan yang lazimnya ditunjukkan dengan nilai tes atau angka nilai yang diberikan oleh guru sesuai dengan tingkat keberhasilan dalam mempelajari materi pelajaran. Hal ini dikarenakan bahwa alasan utama pemakaian media kartu bergambar dalam proses belajar mengajar adalah karena media kartu bergambar mampu menarik perhatian, merangsang respon siswa, memperjelas konsep yang abstrak menjadi konkrit mengatasi batas ruang, waktu, dan tempat sehingga tujuan proses belajar mengajar bisa tercapai.:

3) Peningkatan prestasi belajar siswa dibuktikan pada hasil penelitian yang dicapai dua siklus pada mata pelajaran Ilmu Pengetahuan Sosial dengan menggunakan media kartu bergambar 
(Draw Card). Hasil peningkatan memahami materi yang diajarkan menunjukkan peningkatan yang sangat signifikan, hal ini dibuktikan pada perolehan nilai pra siklus sebelum diterapkannya media kartu bergambar tidak ada siswa yang tuntas (TT) dalam tes formatif, setelah diterapkannya media kartu bergambar pada siklus I mengalami peningkatan sebesar 50\% dan Siklus II meningkat sebesar 90\%, juga mencapai ketuntasan klasikal sebesar 100\%. Hasil ini membuktikan bahwa penerapan media kartu bergambar (Draw Card) dapat meningkatkan prestasi belajar siswa.

\section{Kesimpulan}

Setelah mengamati dan mengevaluasi, perkembangan siswa dalam penelitian Peningkatan Prestasi Belajar Ilmu Pengetahuan Sosial (IPS) Menggunakan Media Kartu Bergambar (Draw Card) Pada siswa kelas VI SDN Tasikmadu 02 Kecamatan Palang Kabupaten Tuban. Dapat disimpulkan sebagai berikut:

1. Penerapan media kartu bergambar (Draw Card) dapat dilakukan dengan baik dan terstruktur oleh peniliti, kegiatan pelaksanaan dilakukan melalui kegiatan pra siklus, kemudian siklus I dan berlanjut pada siklus II

2. Prestasi belajar siswa terus menunjukkan peningkatan yang signifikan dibandingkan sebelum menggunakan media prestasi siswa cenderung rendah yakni 0 atau tidak ada siswa yang tuntas dari kriteria ketuntasan minimal yang sudah ditetapkan. Dapat diketahui bahwa prestasi belajar IPS siswa yang berjumlah 18 siswa, ada 18 siswa atau $100 \%$ yang mendapatkan nilai tuntas (T) dan 0 siswa atau $0 \%$ siswa mendapatkan nilai tidak tuntas (TT). Nilai rata-rata kelasnya adalah 90 .

Prestasi belajar Ilmu Pengetahuan Sosial (IPS) dengan menggunakan media kartu bergambar (Draw Card) telah mengalami peningkatan yang dapat dilihat dari nilai rata-rata dan presentasi ketuntasan klasikal, nilai pra siklus menunjukkan rata-rata 53,89\% dengan presentase siswa yang tuntas $0 \%$. Setelah diterapkannya media kartu bergambar pada siklus I hasil tes formatif mencapai $70 \%$ dengan presentase siswa yang tuntas 9 dan siswa yang tidak tuntas 9, pada siklus II mengalami peningkatan rata-rata sebesar 90\% dan telah mencapai indikator keberhasilan dari ketuntasan klasikal yaitu minimal 85\% dari jumlah keseluruhan siswa. Hal ini menunjukkan bahwa penggunakan media kartu bergambar (Draw Card) dapat meningkatkan prestasi belajar Ilmu Pengetahuan Sosial. 


\section{Daftar Referensi}

Agustin, Nurhaningtyas. 2020. Pengaruh Model Pembelajaran Open Ended Terhadap

Kemampuan Berpikir Kritis Siswa Kelas V Mata Pelajaran Matematika Di MI. Tuban:

IAINU Tuban

Arikunto, Suharsimi. 2008. Prosedur Penelitian Suatu Pendekatan Praktek. Jakarta: Rineka Cipta.

Arifin. 2009. Metodologi Penelitian Pendidikan Filosofi, Teori \& Aplikasinya. Surabaya: Lentera Cendikia

Arsyad, Azhar. 2014. Media Pembelajaran. Jakarta : Rajawali Pers

Asnawir. 2002. Media PembelajaranI. Jakarta : Ciputat Pers

Djamarah dkk. 1996. Strategi Belajar Mengajar. Jakarta : PT Rineka Cipta

Dimyati, Mudjiono. 2002, Belajar dan Pembelajaran. Jakarta : PT Rineka Cipta

Hatibe, Amirudin. 2012, Ilmu Alamiah Dasar. Yogyakarta: SUKA-Press UIN Sunan Kalijaga

Kustandi, Cecep dan Bambang Sutjipto. 2011. Media Pembelajaran; Manual dan Digital. Bogor: Ghalia Indonesia.

Nurjanah, Siti. 2020. Pengembangan Media Pembelajaran Teka-Teki Silang (TTS) Pada Pembelajaran Tematik Tema Cita-Citaku Kelas IV Di MI Al Busyro. Tuban : IAINU Tuban

Rusyan, Tabrani dkk. 1989. Pendekatan dalam proses Belajar Mengajar. Bandung: PT Remaja Rosda Karya

Sanjaya, Wina. 2009, Penelitian Tindakan Kelas. Jakarta : Prenadamedia Group

Slameto. 2010, Belajar dan Faktor-Faktor yang Memepengaruhinya. Jakarta: Rineka

Susanto, Ahmad. 2013, Teori-teori Pembelajaran di Sekolah Dasar. Jakarta: Kencana

Sudjana Nana. 1995. Penelitian Hasil Proses Belajar Mengajar. Bandung : PT Remaja Rosdakarya

Sukmadinat, Nana Syaodih. 2004, Landasan Psikologi Proses Pendidikan. Bandung: Remaja Rosdakarya Offset.

Syah, Muhibbin. 2015. Psikologi Belajar. Jakarta : Rajawali Pers

Sugiyono. 2015, Metode Penelitian Pendidikan Pendekatan Kuantitatif, Kualitatif dan $R \&$ \&. Bandung : Alfabeta

Tohirin. 2014, Bimbingan dan Konseling, Jakarta : Rajawali Pers 
Utomo, Hari Dwiyono. 2010. Pendidikan IPA SD. Tuban: Universitas Ronggolawe Tuban Winkel, W.S. 1996. Psikologi Pengajara. Jakarta: Grasindo 